\title{
PENGARUH PENGGUNAAN METODE PICTURE AND PICTURE TERHADAP HASIL BELAJAR SISWA PADA POKOK BAHASAN EKOSISTEM KELAS X SMAN 17 BATAM
}

\section{THE INFLUENCE OF USED PICTURE AND PICTURE METHOD ON THE SUBJECT DISCUSSION OF ECOSYSTEM TO LEARNING OUTCOMES STUDENT IN CLASS X SMAN 17 BATAM}

\author{
Maryuna Tumanggor ${ }^{1}$, Nurhaty Purnama Sari ${ }^{2}$, Ramses $^{2}$ \\ ${ }^{1}$ Alumni Program Studi Pendidikan Biologi, FKIP, Universitas Riau Kepulauan, Batam \\ ${ }^{2}$ Dosen Program Studi Pendidikan Biologi, FKIP, Universitas Riau Kepulauan, Batam
}

Koresponden: nurhatypurnamasari@gmail.com

\begin{abstract}
Abstrak
Penelitian dilakukan di kelas X SMAN 17 Batam dilakukan pada bulan Maret sampai Mei 2012, bertujuan untuk mengetahui pengaruh pendekatan pembelajaran dengan menggunakan Metode Picture and Picture pada materi Ekosistem. Penelitian ini menggunakan pendekatan metode kuasi-eksperimental (Quasi-Exsperimental) dengan memakai keseluruhan populasi siswa kelas X. Data penelitian adalah hasil dari belajar Ekosistem yakni dengan metode picture dan picture (X1) dan dengan pendekatan konvesional (X2). Analisis data dengan menggunakan teknik statistik diskriptif dan teknik analisis inferensial menggunakan hipotesis Uji t yaitu generalisasi nilai hasil penelitian menggunakan mean perbedaan tes kedua perlakuan dengan pada tingkat $\alpha$ level signifikansi 0,05 . Hasil penelitian ini menyimpulkan: (1) secara keseluruhan, ada pengaruh pendekatan pembelajaran terhadap prestasi belajar siswa (2) Hasil belajar siswa menunjukkan bahwa penggunaan metode picture dan picture cenderung yang lebih baik dibandingkan dengan pendekatan konvensional.
\end{abstract}

Kata Kunci: Metode picture and picture, Ekosistem, Hasil belajar

\begin{abstract}
The study was conducted in classes X SMAN 17 Batam from March to May 2012, that aims to determine the effected of using the method of approach with Picture and Picture with Ecosystem material. This study uses a quasi-experimental approach method (Quasi-Exsperimental) by means of the overall student population class $X$. The research data is a result of studying Ecosystem follow by the method of picture and picture (X1) and the conventional approach (X2). Analysis of data using statistical techniques descriptive and inferential analysis technique using t-test the hypothesis that generalization value using the research results mean treatment difference with the second test at the $\alpha=0.05$ level of significance level. The results of this study concluded: (1) overall, there is an influence learning approaches on student achievement (2) The results showed that students' use of methods picture and picture are likely better than the conventional approach.
\end{abstract}

Keywords : Method picture and picture, Ecosystem, Learning outcomes

\section{PENDAHULUAN}

Belajar adalah suatu proses yang kompleks yang terjadi pada semua orang dan berlangsung seumur hidup. Salah satu pertanda bahwa seorang telah belajar sesuatu adalah perubahan tingkah laku dalam dirinya. Menurut Abdillah (2002) dalam 
Aunurrahman (2008), belajar adalah suatu perubahan di dalam kepribadian yang menyatakan diri sendiri sebagai pola baru dari reaksi berupa kecakapan, sikap, kebiasaan, kepribadian atau suatu pengertian. Dimana tingkah laku ditimbulkan atau diubah melalui latihan atau pengalaman.

Menurut Martiningsih (2007) metodologi mengajar adalah ilmu yang mempelajari cara-cara untuk melakukan aktivitas yang tersistem dari sebuah lingkungan, yang terdiri dari pendidik dan peserta didik, untuk saling berinteraksi dalam melakukan suatu kegiatan, sehingga proses belajar berjalan dengan baik dan tujuan pengajaran tercapai. Suprijono (2009) mengemukakan bahwa tujuan belajar sangat banyak dan bervariasi. Tujuan belajar yang eksplisit disusahakan untuk dicapai dengan tindakan instruksional, lazim dinamakan instructional effects, biasa berbentuk pengetahuan dan keterampilan.

Penelitian tentang menggunakan metode picture and picture sebelumnya diteliti oleh (Husna, 2011) Terhadap Hasil Belajar Siswa Pada Materi Pokok Ekosistem dapat meningkatkan hasil belajar biologi siswa di kelas X SMAN 1 Batang Kuis Tahun Pelajaran 2011/2012. Dalam penelitian tersebut dibuktikan dari hasil analisis diperoleh data pretes sebagai hasil belajar awal siswa dengan rata-rata nilai 42,76, data postes siklus I diperoleh rata-rata nilai 66,59, dan data postes pada siklus II diperoleh rata-rata nilai 73,72 .

Maka tujuan penelitian ini adalah. (1) Untuk mengetahui pengaruh hasil belajar biologi siswa dengan menggunakan metode picture and picture, dan (2) Untuk mengetahui peningkatan pada hasil belajar siswa pada pokok bahasan Ekosistem dikelas X SMAN 17 Batam Tahun Pelajaran 2012/2013”.

\section{METODOLOGI}

Penelitian ini menguji pengaruh menggunakan metode picture and picture terhadap hasil belajar siswa di kelas X SMAN 17 Batam. Jenis penelitian menggunakan metode exprimen (Experiment). Dalam penelitian ini siswa dibagi dalam 2 (dua) kelas, yaitu kelas eksperimen $\left(\mathrm{X}_{1}\right)$ menggunakan metode picture and picture dan kelas control $\left(\mathrm{X}_{2}\right)$. Bentuk rancangan penelitian eksperimen yang digunakan adalah Randomized Posttest Only Control Group Design (Riyanto, 2010). Data dalam penelitian ini dikumpulkan dengan menggunakan alat tes dan pedoman observasi. Tes digunakan 
untuk memperoleh data tentang pengaruh metode picture and picture terhadap hasil belajar pada siswa. Instrumen tes yang digunakan terdiri atas 25 item soal pada setiap kelas eksperimen dan kelas kontrol, Agar dalam penyusunan tes dapat mengukur aspek yang diperlukan dan sesuai dengan pokok dan sub pokok bahasan yang diajarkan, maka terlebih dahulu disusun kisi-kisi tes (Sujana, 1989).

Kaitannya dengan uji coba tes tersebut maka dilakukan (a) uji validitas, (b) uji reliabilitas, (c) uji tingkat kesukaran, dan (d) uji daya beda. Selanjutnya butir soal yang telah tervalidasi digunakan menjaring data dalam penelitian, seperti mengadakan postes pada setiap kelas. Siswa yang dianggap tuntas belajar, bila telah mencapai nilai 6,5 ke atas atau $65 \%$, siswa yang mendapat nilai kurang dari 6,5 dinyatakan belum tuntas belajar. Pengadaan postes dilaksanakan pada setiap akhir siklus sedangkan untuk mengamati kegiatan guru dan siswa digunakan pedoman observasi.

\section{PEMBAHASAN}

Berdasarkan analisis data nilai akhir siswa memperlihatkan sampel yang homogen dengan data yang berdistribusi normal. Keadaan ini menunjukan bahwa sebelum melakukan perlakuan memiliki kemampuan yang sama sehingga kelas eksperimen diberikan metode picture and picture dan pada kelas kontrol diberi metode ceramah. Nilai rata-rata dengan menggunakan metode picture and picture $\left(\mu \mathrm{X}_{1}\right)$ sebesar 80.03 lebih baik dibandingkan dengan siswa yang mengikuti pembelajaran dengan menggunakan metode ceramah dengan rerata nilai $\left(\mu X_{2}\right)$ sebesar 69.72.

Berdasarkan hasil perhitungan uji beda menggunakan Uji t satu pihak, diperoleh nilai t hitung $\left(t_{\text {hit }}\right)$ sebesar 2.25 sedangkan nilai $t_{\text {tabel }}(\alpha=0,05 ; \mathrm{dB}=39)$ dengan jumlah sampel untuk setiap kelompok perlakuan $(n)$ sebanyak $40(\mathrm{~dB}=39)$ siswa nilainya sebesar 2,02. Jadi $t_{\text {hit }}>t_{\text {tabel }}$ maka pengujian menerima hipotesis $\left(\mu_{\mathrm{a}}\right)$, yaitu terdapat perbedaan hasil belajar antar kelompok siswa yang mengikuti pembelajaran dengan menggunakan Metode Picture and Picture (X1) dengan siswa yang mengikuti pembelajaran dengan menggunakan metode ceramah (X2).

Hasil penelitian membuktikan bahwa siswa yang mengikuti pembelajaran dengan menggunakan metode picture and picture mencapai prestasi belajar yang lebih baik dibandingkan dengan siswa yang mengikuti pembelajaran dengan menggunakan metode ceramah. Berdasarkan hasil penelitian, dapat ditarik kesimpulan bahwa 
pembelajaran ekosistem menggunakan Metode picture and picture lebih sesuai digunakan untuk pencapaian kompetensi pemahaman dan penerapan konsep dalam pembelajaran ekosistem.

Pencapaian keberhasilan belajar yang lebih baik dapat dicapai karena dalam pembelajaran siswa dilibatkan secara aktif dengan berbagai pengalaman langsung di lapangan untuk mengamati ekosistem yang ada di alam pada proses pembelajaran yang dipelajari, serta pada akhirnya mampu menarik kesimpulan dan menemukan suatu pengetahuan yang relevan dengan materi yang dipelajarinya.

\section{KESIMPULAN}

Berdasarkan hasil pengujian hipotesis dan pembahasan maka dapat ditarik beberapa kesimpulan dari penelitian ini, yaitu:

1. Terdapat pengaruh penggunaan Metode picture and picture, dalam pembelajaran ekosistem terhadap hasil belajar siswa di SMAN 17 Batam pada khususnya di kelas $\mathrm{X}$.

2. Hipotesis penelitian yang diajukan, yaitu hasil belajar siswa yang mengikuti pembelajaran dengan menggunakan Metode picture and picture lebih baik dibandingkan dengan hasil belajar siswa yang mengikuti proses pembelajaran dengan menggunakan metode ceramah.

3. Hasil pengujian hipotesis diterima $\left(\mathrm{H}_{\mathrm{a}}\right)$, artinya terdapat perbedaan hasil belajar siswa yang mengikuti pembelajaran ekosistem menggunakan Metode picture and picture dengan hasil belajar siswa yang mengikuti pembelajaran dengan menggunakan metode ceramah.

4. Proses pembelajaran dengan menggunakan Metode picture and picture mencapai prestasi belajar biologi siswa yang lebih baik karena dengan menggunakan Metode picture and picture siswa lebih kreatif untuk mengutarakan pendapatnya masingmasing dalam kegiatan pembelajaran relevan dengan materi yang dipelajarinya.

\section{REFERENSI}

Aunurrahman. 2008. Belajar dan Pembelajaran. Gramedia, Jakarta.

Jamal, 2011. 7 Tips Aplikasi PAKEM. Diva press, Jogjakarta.

Mulyatiningsih, 2012. Metode Penelitian Terapan Bidang Pendidikan. Nusa Media. Bandung. 
Sukarno, 2001. Dasar-Dasar Pendidikan Sains. Bahtara Karya Aksara. Alfabeta, Jakarta.

Silberman, 2011. Active Learning, 101 Cara Belajar Siswa Aktif, Bandung.

Suprijono, 2009. Belajar dan Pembelajaran. Prospect. Bandung. 